\title{
Implementasi Kegiatan Ekstrakurikuler English Club dalam Mengembangkan Kecerdasan Linguistik Siswa MIN 2 Sleman
}

\author{
Noor Mas'udah', Ahmad Shofiyuddin Ichsan ${ }^{2}$, Mujawazah $^{3}$ \\ ${ }^{123}$ Institut Ilmu Al Qur'an An Nur Yogyakarta \\ Email: noormasudah97@gmail.com, ahmad.shofiyuddin.ichsan@gmail.com, \\ mujawazah2408@gmail.com
}

\begin{abstract}
Abstrak
Penelitian ini mengungkapkan tiga pembahasan, yakni bagaimana implementasi ekstrakurikuler English Club di MIN 2 Sleman, bagaimana hasil yang dicapai dalam kegiatan ekstrakurikuler tersebut dilihat dalam konteks kecerdasan linguistiknya, dan apa saja faktor pendukung dan penghambat selama kegiatan ekstrakurikuler ini berjalan. Penelitian ini adalah penelitian kualitatif dengan pendekatan fenomenologi. Metode pengumpulan data menggunakan observasi, wawancara, dan dokumentasi. Sedangkan Teknik Analisis Data merujuk pada Miles dan Hubberman, yakni data reduction (reduksi data), data display (penyajian data), dan conclusion drawing/Verification (menarik kesimpulan). Hasil dari penelitian ini adalah implementasi ekstrakurikuler ini meliputi dua tahapan, yakni tahapan persiapan dan tahapan proses. Sedangkan hasil perkembangan kecerdasan linguistik siswa melalui kegiatan ekstrakurikuler English Club ini mencakup keterampilan mendengar, keterampilan berbicara, keterampilan menulis, dan keterampilan membaca. Adapun faktor pendukungnya adalah peran kepala madrasah yang kuat, kualitas guru yang profesional, minat dan kecerdasan siswa yang baik, dan alat atau media yang mudah didapat. Sedangkan faktor penghambatnya antara lain kegiatan ini bukan materi wajib, kurangnya minat bimbingan di rumah, dan media pembelajaran yang belum diperbarui.
\end{abstract}

Kata Kunci: Ekstrakurikuler English Club, Kecerdasan Linguistik, Madrasah Ibtidaiyah

\section{PENDAHULUAN}

Madrasah Ibtidaiyah (MI) adalah lembaga pendidikan sederajat Sekolah Dasar (SD) di bawah naungan Kementerian Agama (Kemenag). Sebagai implementasi dari UU Sisdiknas Nomor 2/1989 dan sejumlah peraturan di bawahnya, pada tahun 1993 Menteri Agama (melalui Keputusan Menteri Agama Nomor 371, 372, 373/1993) menetapkan Kurikulum Madrasah MI, MTs, dan MA yaitu minimal sama dengan kurikulum sekolah (SD, SLTP, dan SMU sesuai jenjangnya), ditambah materi keagamaan yang meliputi; Qur'an-Hadits, Aqidah-Akhlak, Fiqh, Sejarah Kebudayaan Islam, dan Bahasa Arab (Kosim, 2008:55-56).

Madrasah Ibtidaiyah berperan dalam mengembangkan potensi siswa dari berbagai aspek seperti aspek religius, aspek intelektual, aspek karakter, dan pengalaman bagi siswa. Semua mata pelajaran yang diprogramkan oleh madrasah bertujuan saling melengkapi dalam pengembangan aspek-aspek di atas. Proses pembelajaran terbagi menjadi pembelajaran intrakurikuler, kokurikuler, dan ekstrakurikuler. Dalam Peraturan Menteri Pendidikan dan Kebudayaan RI Nomor 62 Tahun 2014 tentang Kegiatan Ekstrakurikuler pada Pendidikan Dasar dan Menengah Pasal 1 disebutkan bahwa ekstrakurikuler adalah kegiatan yang dilakukan oleh siswa di luar jam belajar, yakni di luar belajar intrakurikuler dan kokurikuler di bawah bimbingan dan pengawasan satuan pendidikan (Mendikbud, 2014:2).

Ekstrakurikuler bertujuan untuk menumbuh kembangkan potensi sumber daya manusia (SDM) yang dimiliki siswa baik berkaitan dengan aplikasi ilmu pengetahuan yang didapatkannya maupun untuk membimbing siswa dalam mengembangkan potensi dan bakat yang ada pada dirinya melalui 
kegiatan yang wajib maupun pilihan (Departemen Agama RI, 2005:9). Dengan demikian, kegiatan ekstrakurikuler adalah wahana pengembangan pribadi siswa melalui aktivitas, baik secara langsung maupun tidak langsung terkait dengan materi kurikulum, sebagai bagian yang tidak lepas dari tujuan kelembagaan sekolah (Prihatin, 2011:172).

Salah satu madrasah yang telah berhasil mengasah kecerdasan linguistik pada siswa dalam bentuk keterampilan berbahasa melalui kegiatan ekstrakurikuler adalah Madrasah Ibtidaiyah Negeri (MIN) 2 Sleman. Kegiatan ekstrakurikuler tersebut adalah English Club. Penguasaan Bahasa Inggris merupakan kunci berkomunikasi dengan bangsa lain. Maka sebagai bahasa internasional, mayoritas negara di dunia mempelajari dan menggunakannya.

Madrasah Ibtidaiyah Negeri (MIN) 2 Sleman adalah madrasah berstatus negeri yang didirikan pada tanggal 31 Mei 1980 sesuai SK Pendirian No. 27 tahun 1980. MIN 2 Sleman beralamat di Jalan Kaliurang KM 9,3 Dusun Sinduharjo, Kecamatan Ngaglik, Kabupaten Sleman, Daerah Istimewa Yogyakarta dengan Nomor Pokok Sekolah Nasional (NPSN) 60714127. MIN 2 Sleman terakreditasi A sesuai sertifikat ISO.

Menurut Elly Fatmawati selaku pembina kegiatan ekstrakurikuler English Club di MIN 2 Sleman, ekstrakurikuler ini adalah program yang dikelola madrasah untuk mengenalkan Bahasa Inggris secara mendasar lebih dini agar siswa dapat mengembangkan keterampilan berbahasa yang meliputi menulis, membaca, dan berbicara dengan Bahasa Inggris di tingkat sekolah selanjutnya setelah lulus. Ekstrakurikuler ini diikuti siswa dari kelas I sampai kelas IV. Dalam English Club, siswa difokuskan untuk memahami dan menguasai kosakata (vocabulary) Bahasa Inggris. Karena jika siswa belajar memahami dan menguasai kosakata, secara tidak langsung siswa telah mengasah keterampilan reseptif melalui kegiatan listening (mendengar), reading (membaca) dan keterampilan produktif melalui kegiatan writing (menulis), speaking (berbicara) (Wawancara personal dengan EF, 13 April 2019).

Membaca, menulis, dan berbicara merupakan kegiatan-kegiatan yang dapat mengasah kecerdasan berbahasa (linguistik) yang ada pada diri siswa. Pada dasarnya, kecerdasan linguistik dimiliki siswa dengan kecenderungan mudah memahami informasi yang disampaikan dalam bentuk bahasa, senang menuangkan idenya dengan menulis, senang mendengarkan cerita dan bercerita, menunjukkan ketertarikannya pada bahasa dan lebih mudah untuk mempelajari berbagai macam bahasa (Mini, 2010:44). Menurut seorang ahli pendidikan dari Universitas Harvard bernama Howard Gardner sebagaimana dikutip oleh Nini Subini, berpendapat bahwa tidak ada manusia yang tidak cerdas. Gardner berpendapat bahwa kecerdasan adalah kapasitas yang dimiliki seseorang untuk menyelesaikan masalah dan membuat cara penyelesaian dalam konteks yang beragam dan wajar. Dalam pandangannya, kecerdasan yang dimiliki seseorang tidak hanya satu, namun masing-masing orang mempunyai kecerdasan yang berbeda-beda yang disebut dengan kecerdasan majemuk atau kecerdasan ganda (multiple intelligence) (Subini, 2011:72).

Implementasi kegiatan ekstrakurikuler English Club di MIN 2 Sleman sudah berjalan sejak tahun 2010 dan didesain oleh tim pengembang English Club yang terdiri dari satu guru dari madrasah dan dua guru dari luar madrasah. Setiap hari Senin hingga Kamis, English Club dilaksanakan bergilir dari kelas I hingga kelas IV. Ketiga guru mengampu sesuai jumlah kelas paralel yaitu a, b, dan c. Peran guru sangat diutamakan dalam menciptakan pembelajaran yang menyenangkan, mudah dipahami, dan tidak membosankan (Wawancara personal dengan EF, 13 April 2019).

Perkembangan minat siswa mengikuti kegiatan ekstrakurikuler English Club di MIN 2 Sleman sangat signifikan. Sejak dimulai pada tahun 2010 hingga saat ini sebanyak 80\% siswa mengikuti ekstrakurikuler tersebut dan menumbuhkan karakter yang berbeda dari siswa yang tidak mengikutinya. Siswa yang mengikuti kegiatan ekstrakurikuler ini lebih tampil percaya diri, riang, dan bersemangat. Kegiatan ekstrakurikuler English Club di MIN 2 Sleman kini menjadi ekstrakurikuler kedua yang paling diminati setelah ekstrakurikuler tahfidzul qur'an (Wawancara personal dengan EF, 13 April 2019). 
Dari konteks ini, tiga topik pembahasan akan peneliti uraikan, yakni bagaimana implementasi kegiatan English Club di MIN 2 Sleman, bagaimana hasil yang dicapai dalam kegiatan ekstrakurikuler tersebut dilihat dari kaca mata kecerdasan linguistik siswa, dan apa saja faktor pendukung serta penghambat selama kegiatan ekstrakurikuler English Club tersebut berjalan. Dengan ketiga uraian tersebut, penelitian ini diharapkan dapat memberikan wawasan mengenai pelaksanaan kegiatan esktrakurikuler dalam konteks kecerdasan bahasa (linguistik) melalui aktivitas menulis, membaca, mendengar, dan berbicara siswa di MIN 2 Sleman, sehingga dengan itu menjadikannya sebagai program yang unggul dan terus menerus diinovasikan, baik dari desainnya maupun fasilitas pendukungnya seiring kebutuhan perkembangan diri siswa di sekolah-sekolah. Tidak hanya itu, penelitian ini diharapkan menjadi referensi bagi masyarakat luas untuk berinisiatif 'me-madrasah-kan' anak-anaknya di Madrasah Ibtidaiyah, karena bagaimanapun Madrasah adalah sekolah pilihan yang tidak hanya mempelajari agama, tetapi juga ilmu pengetahuan global.

Berbagai penelusuran akademik tentang penelitian serupa, peneliti belum menemukan secara spesifik ekstrakurikuler English Club dikaitkan dengan kecerdasan linguistik di Sekolah Dasar atau Madrasah Ibtidaiyah. Hasil penelitian yang terkait tema ini pernah diteliti oleh Arina Mustafidah (2017), Laeliya Masruroh (2016), Annis Kurniawati (2011), Jumiyati (2018), dan Widya Syahra Martyawati (2016). Maka dari itu, penelitian ini memiliki perbedaan dengan penelitian-penelitian sebelumnya, sehingga peneliti perlu menguraikan lebih komprehensif bagaimana hubungan ekstrakurikuler English Club dikaji dalam konteks kecerdasan linguistiknya.

\section{METODE/EKSPERIMEN}

Penelitian ini merupakan penelitian kualitatif dengan studi lapangan (field research). Yang dimaksud pendekatan kualitatif yaitu proses penelitian yang bertujuan mendalami kejadian-kejadian yang dirasakan peneliti. Penelitian ini bersifat deskriptif, yaitu penelitian yang menghasilkan data berupa kata-kata tertulis berdasarkan sumber data. Strategi penelitian yang digunakan oleh peneliti adalah studi fenomenologi.

Fenomenologi adalah ikhtiar secara langsung melukiskan pengalaman peneliti sebagaimana adanya tanpa memperhatikan asal usul psikologinya (Hasbiansyah, 2008:167). Peneliti yang menggunakan metode fenomenologi harus mendekati objek penelitiannya dengan pikiran polos tanpa asumsi, praduga, prasangka ataupun konsep dan membiarkan partisipan mengungkapkan pengalamannya, sehingga nantinya akan diperoleh hakikat terdalam dari pengalaman tersebut. Peneliti juga harus mengenal dan memahami konteks pengalaman partisipan, sehingga penafsiran atas pengalaman itu akurat dan dapat menghasilkan nuansa dan teori baru (Racho, 2010:84).

Objek dalam penelitian ini bertempat di MIN 2 Sleman yang beralamat di Jalan Kaliurang KM 9,3 Dusun Sinduharjo, Kecamatan Ngaglik, Kabupaten Sleman, Daerah Istimewa Yogyakarta. Sedangkan subjek yang diteliti adalah kepala MIN 2 Sleman, Wakil Kepala MIN 2 Sleman, guru pembimbing ekstrakurikuler English Club, siswa kelas 2 sampai kelas 4, dan alumni yang telah mengikuti kegiatan ekstrakurikuler tersebut.

Adapun metode pengumpulan data, peneliti menggunakan observasi, wawancara, dan dokumentasi (Sugiyono, 2018:316-318). Sedangkan Teknik Analisis Data merujuk pada Miles dan Hubberman, yakni aktivitas analisis data dilakukan secara terus menerus, sehingga datanya jenuh. Aktivitas dalam analisis data tersebut yaitu data reduction (reduksi data), data display (penyajian data), dan conclusion drawing/Verification (menarik kesimpulan) (Sugiyono, 2018:334). Untuk teknik pemeriksaan keabsahan data, peneliti menggunakan uji kredibilitas dengan triangulasi. Triangulasi sendiri merupakan teknik pemeriksaan keabsahan data yang digunakan untuk memanfaatkan keperluan pengecekan atau digunakan sebagai pembanding terhadap data tersebut. Triangulasi yang digunakan pada penelitian ini adalah triangulasi sumber, yakni sumber yang digunakan untuk membandingkan dan 
mengecek kembali derajat kepercayaan suatu data informasi yang diambil melalui alat dan waktu yang berbeda dalam sebuah penelitian, khususnya penelitian kualitatif (Moelong, 2011:330).

\section{Kecerdasan Linguistik: Sebuah Konsep}

Kecerdasan linguistik adalah kecerdasan dalam mengolah kata. Dalam artian, kecerdasasan ini merupakan kemampuan individu seseorang dalam menggunakan kata-kata secara baik dan efektif, baik secara lisan maupun tulisan. Kecerdasan ini mencakup kepekaan arti kata, ritme, dan intonasi dari kata yang diucapkan untuk menyampaikan informasi (Jannah, 2018:3). Bahasa merupakan sarana efektif untuk menjalin komunikasi sosial. Bahasa mempunyai dua fungsi. Pertama, bahasa sebagai sarana pembangkit dan pembangun hubungan yang memperluas pikiran seseorang sehingga mentalnya menjadi bagian yang tidak terpisahkan dari mental kehidupan kelompoknya. Kedua, bahasa sebagai sarana mempengaruhi kepribadian (Djamarah, 2008:46). Dalam praktiknya, kecerdasan linguistik ini dapat dilakukan dan diasah dengan cara menyimak, memperhatikan, dan menirukan pembimbing dalam melafalkan suatu pelajaran (Ichsan, 2020:90).

Salah satu kecerdasan dalam multiple intelligences yang dikemukakan oleh Howard Gardner sebagaimana dikutip oleh Rina Roudhotul Jannah (2018) yaitu kecerdasan berbahasa verbal-linguistik yang mencakup kemampuan menguraikan pikiran dalam kalimat-kalimat, presentasi, pidato, diskusi, dan tulisan. Dalam kehidupan sehari-hari, sering kita jumpai seseorang yang pandai merangkai kata sehingga mengantarkannya menjadi pendongeng maupun penceramah profesional. Oleh karena itu, ada beberapa faktor yang mempengaruhi kecerdasan linguistik pada anak adalah sebagai berikut:

a. Faktor genetik

Kecerdasan Linguistik berasal dari dalam diri anak tersebut, yang berarti Kecerdasan Linguistik dapat dipengaruhi sebab genetik.

b. Faktor kesehatan dan fisik

Perkembangan dan pemerolehan bahasa mensyaratkan berbagai kondisi fisik, terutama pada organ bicara (gigi, bibir, lidah, tenggorokan, dan pita suara), organ pendengaran (telinga), dan sistem neuromuscular di otak. Agar perkembangan bahasa anak dapat berkembang secara normal, maka organ tersebut harus dapat berfungsi dengan baik.

c. Status sosial ekonomi keluarga

Anak yang berasal dari keluarga yang kurang mampu biasanya mengalami keterlambatan dalam perkembangan bahasanya dibanding dengan anak yang berasal dari keluarga mampu. Orang tua dengan taraf ekonomi menengah ke atas memiliki pendidikan yang cukup untuk menfasilitasi perkembangan bahasa anak dan menyediakan berbagai alat bantu sebagai media pengembangan bahasa. Dan orang tua pun lebih memperhatikan cara bicara anak dan menuntun anak untuk bicara dengan baik dan benar.

d. Jenis kelamin

Secara biologis dan sosial, perkembangan bahasa pada anak perempuan lebih cepat daripada anak laki-laki. Hal ini disebabkan perkembangan hemisfer celebral yang terdapat pada otak kiri anak perempuan muncul lebih cepat, dan inilah yang berperan besar dalam perkembangan linguistik pada anak. Selain itu kebiasaan anak perempuan berinteraksi dengan orang tua seperti membantu ibu di dapur, bermain dengan boneka dan mengajaknya berbicara. Sementara anak lakilaki lebih diarahkan pada kegiatan yang merangsang kemampuan motorik sehingga membuat anak laki-laki lebih banyak bergerak daripada berbicara.

e. Bilingualisme (2 bahasa)

Bilingual atau penguasaan dua bahasa merupakan sesuatu yang sedang tren saat ini. Hal ini bertujuan agar tidak tertinggal perkembangan jaman, khususnya bagi orang tua yang tinggal di 
kota-kota besar mulai memasukkan anaknya pada sekolah yang menerapkan dua bahasa atau lebih (Dewi, 2020).

Tidak semua aktivitas pembelajaran sesuai dengan kondisi nyata lembaga pendidikan di Indonesia. Maka Muhammad Yaumi dalam jurnalnya menyimpulkan ada empat strategi pembelajaran berbasis kecerdasan linguistik yang dianggap mewakili keterampilan reseptif dan produktif, yaitu:

a. Sumbang Saran (Brain Stroming)

Sumbang saran adalah teknik kretifitas kelompok untuk mencoba menemukan solusi terhadap persoalan yang dihadapi dengan mengumpulkan sejumlah paparan ide secara spontan, tetapi juga membutuhkan aktivitas terstruktur dan mengikuti pola aturan dan prosedur tertentu.

b. Bercerita (Story Telling)

Bercerita adalah menyampaikan peristiwa melalui kata-kata, gambar, atau suara yang dilakukan dengan menambah-nambah dengan maksud untuk memperindah jalannya cerita. Bercerita merupakan aktivitas pembelajaran yang dapat berkontribusi pada kemampuan menyajikan informasi, konsep, dan ide-ide, serta dapat mengintegrasikannya ke dalam tujuan pembelajaran yang dapat disampaikan secara langsung kepada siswa.

c. Menulis Jurnal

Menulis jurnal adalah aktivitas menulis secara teratur tentang pengalaman dan pikiran dalam proses pembelajaran. Jurnal mencakup gambaran tentang pengalaman belajar, refleksi perasaan dan emosi, pemahaman, dan bentuk keterampilan yang diperoleh dari hasil aktivitas pembelajaran.

d. Membaca Biografi

Membaca biografi orang bukan hanya memberi pengetahuan yang mendalam tentang sejarah masa lalu ke pada siswa, tetapi juga memberi inspirasi baru untuk merencanakan dan merekayasa masa depan. Selain itu, siswa juga dapat membuat biografi dirinya sendiri atau orang lain dengan mengumpulkan sedikit demi sedikit pengalaman hidup yang pernah dialami melalui kumpulan tulisan (Sulaiman, 2015: 194-196).

\section{Implementasi Ekstrakurikuler English Club di MIN 2 Sleman}

Ekstrakurikuler English Club di MIN 2 Sleman dikembangkan oleh tim yang terdiri dari satu guru dari dalam masdrasah dan dua guru dari luar madrasah. Tim ini dibimbing oleh pembina tim pengembangan kegiatan ekstrakurikuler English Club, yaitu Ibu Elly Fatmawati. Ekstrakurikuler English Club dilaksanakan setiap hari senin sampai hari kamis pukul 13.00 sampai 14.00 WIB. Esktrakurikuler English Club diikuti kelas I sampai kelas IV. Setiap harinya ketiga guru tersebut mengampu sesuai jumlah paralel kelas yaitu kelas a, b, dan c (Wawancara personal dengan EF, 13 April 2019).

Dalam implementasinya, kegiatan ekstrakurikuler English Club di MIN 2 Sleman di bagi menjadi dua tahapan, yaitu sebagai berikut:

\section{a. Tahap persiapan}

Tahapan persiapan merupakan rencana bagi guru untuk melaksanakan kegiatan dan menfasilitasi anak dalam proses kegiatan esktrakurikuler English Club. Sebelum kegiatan ekstrakurikuler ini dilaksanakan, tim pengembang memprioritaskan pemahaman dan penguasaan siswa pada materi kosa kata Bahasa Inggris (vocabulary) dan materi percakapan sehari-hari (conversation). Sehingga apapun metode dan media guru di kelas, tidak lepas dari tujuan tersebut. Dan tentunya terus menerus diadakan evaluasi guna mengembangkan kualitas kegiatan ekstrakurikuler ini (Wawancara personal dengan EF, 9 Januari 2020).

Untuk memaksimalkan program ini, keadaan guru dan siswa adalah komponen terpenting sebelum proses kegiatan ekstrakurikuler ini dilaksanakan. Keadaan guru baik sebagai tim maupun pembimbing kegiatan ekstrakurikuler English Club di MIN 2 Sleman sudah berkualitas sangat baik karena berasal dari latar pendidikan Bahasa Inggris dan mempunyai kemampuan dalam berbagai 
bidang, baik dari penguasaan kosa kata (vocabulary), percakapan sehari-hari (conversation), maupun tampil di panggung (perform) (Wawancara personal dengan TW, 9 Januari 2020).

Sementara itu, siswa yang mengikuti ekstrakurikuler English Club sudah siap menerima pembelajaran di ekstrakurikuler ini secara mental dan materi. Hal ini disebabkan oleh beberapa faktor, yaitu minat dari siswa sendiri, hobi membaca beberapa bahasa di perpustakaan daerah, mendapat dukungan orang tua yang berlatar belakang pendidikan tinggi, fasilitas yang memadai dari orang tua, dan kesadaran siswa serta orang tua akan pentingnya mengenal bahasa asing sejak dini untuk bekal masa depan (Wawancara personal dengan siswa, 30 Januari 2020). Secara tidak langsung, kegiatan ekstrakurikuler ini mengembangkan kecerdasan linguistik pada siswa dengan kegiatan mendengar, membaca, menulis, dan berbicara ketika proses pelaksanaan. Hal ini membuat siswa mempunyai kebiasaan yang mencerminkan senang dengan keterampilan produk bahasa.

b. Tahap Pelaksanaan

Kegiatan ekstrakurikuler English Club di MIN 2 Sleman sudah berjalan dengan baik. Berdasarkan pengamatan peneliti di kelas, materi yang disampaikan guru untuk siswa berorientasi pada penguasaan kosa kata dan kepercayaan diri siswa untuk berbicara dengan Bahasa Inggris walau hanya satu dua kata bagi kelas rendah. Selama proses kegiatan, Guru mengutamakan keaktifan siswa untuk merangsang daya pikir yang kritis pada siswa.

Dalam proses pelaksanaan, terdapat beberapa komponen yang tidak lepas dari proses pembelajaran di kegiatan ekstrakurikuler English Club, yaitu sebagai berikut:

a. Sumber Pembelajaran

Yakni, buku yang menjadi acuan mengajar. Guru pembina ekstrakurikuler English Club menggunakan buku Bahasa Inggris dari penerbit Yudistira dan Airlangga. Kemudian dikaji ulang dan dijabarkan dalam bentuk modul untuk dibagikan ke siswa agar lebih terjangkau dan mudah untuk dipelajari. Namun terkadang guru juga membagi hand out khusus beberapa materi beserta lembar soal untuk dikerjakan siswa. Dan dengan kesadaran diri siswa, siswa mempunyai kamus Bahasa Inggris sendiri untuk mempermudah belajar. (Wawancara personal dengan EF, 9 Januari 2020).

b. Tujuan Pembelajaran

Yakni, pedoman dan sasaran yang akan dicapai dalam pembelajaran (Dasopang, 2017:342). Tujuan adanya kegiatan ekstrakurikuler English Club di MIN 2 Sleman adalah mengenalkan bahasa asing sejak dini pada siswa dengan penguasaan kosa kata, percakapan sehari-hari, sehingga dapat mengasah kecerdasan bahasa (linguistik) pada siswa dengan membiasakan membaca, menulis, mendengarkan, dan berbicara dengan Bahasa Inggris (Wawancara personal dengan IA,4 Maret 2019).

c. Materi Pembelajaran

Yakni, substansi pokok yang akan disampaikan kepada siswa dalam proses belajar mengajar (Dasopang, 2017:343). Materi yang disampaikan di kegiatan esktrakurikuler English Club adalah kota kata Bahasa Inggris (vocabulary) dan percakapan sehari-hari (conversation). Materi dimulai dari hal-hal sederhana yang ada di sekeliling siswa dari nama benda di kelas, nama hari, nama bulan, nama buah, nama anggota kelurga dan tema-tema ringan yang sesuai dengan tingkatan kelas. Selain itu diimbangi dengan melatih berbicara dengan Bahasa Inggris dari mengenalkan diri, salam dan menyapa, menanyakan kabar, dan percakapan sehari-hari yang mudah untuk siswa. Minimal dipraktikkan ketika proses kegiatan ekstrakurikuler hendak dimulai (Wawancara personal dengan EF, 9 Januari 2020).

d. Metode Pembelajaran

Yakni, cara atau strategi guru untuk menyampaikan materi dengan menciptakan lingkungan belajar yang mudah dipahami siswa selama pembelajaran (Dasopang, 2017:344-345). Pada proses kegiatan ekstrakurikuler English Club di MIN 2 Sleman, guru menerapkan metode ceramah, diskusi, 
tanya jawab, permainan dan penugasan. Beberapa metode tersebut dikombinasikan agar keaktifan dan inisiatif siswa berkembang, dan tentunya melatih kepercayaan diri siswa (Observasi peneliti, 23 Januari 2020). Adapun langkah-langkah pembelajaran pada kegiatan ekstrakurikuler English Club adalah sebagai berikut:

Tabel. 1

Langkah-langkah Kegiatan Ekstrakurikuler English Club

\begin{tabular}{|c|c|c|}
\hline No & Langkah & Jenis Kegiatan \\
\hline 1 & Pembukaan & $\begin{array}{l}\text { a) Guru memberi salam dan saling menyapa dengan siswa } \\
\text { menggunakan Bahasa Inggris. } \\
\text { b) Guru mengajak siswa menyanyikan yel-yel dengan } \\
\text { Bahasa Inggris sambil tepuk-tepuk tangan dan jari. } \\
\text { c) Guru melakukan pre-test tentang materi pertemuan } \\
\text { sebelumnya. } \\
\text { d) Guru membagikan hand out. }\end{array}$ \\
\hline 2 & Pelaksanaan & $\begin{array}{l}\text { a) Guru membuka materi dengan ceramah, siswa } \\
\text { menyimak. } \\
\text { b) Guru mengenalkan kosa kata baru, siswa diminta } \\
\text { mengulanginya beberapa kali. } \\
\text { c) Guru memberi jeda untuk memberi kesempatan tanya } \\
\text { jawab perihal materi yang disampaikan. } \\
\text { d) Siswa membaca kembali kemudian diminta berdiskusi } \\
\text { tentang gambar yang ada pada hand out. } \\
\text { e) Siswa diberi tugas memahami teks dan diminta } \\
\text { mengerjakan. } \\
\text { f) Setelah dikerjakan, guru membahas soal jawab yang ada } \\
\text { pada hand out, dan siswa yang diminta menjawab sesuai } \\
\text { arahan guru. }\end{array}$ \\
\hline 3 & Penutup & $\begin{array}{l}\text { a) Guru mengulang beberapa pertanyaan dan siswa diminta } \\
\text { menyebutkan beberapa hal tentang materi hari ini. } \\
\text { b) Siswa diberi tugas mempelajari materi selanjutnya yang } \\
\text { ada pada hand out untuk pertemuan selanjutnya. } \\
\text { c) Guru menutup dengan salam, dan sebelum pulang guru } \\
\text { memberi permainan tebak-tebakan kosa kata untuk } \\
\text { dijawab siswa. Bagi siswa yang cepat dan benar } \\
\text { menjawab, maka siswa diperbolehkan pulang terlebih } \\
\text { dahulu. }\end{array}$ \\
\hline
\end{tabular}

Sumber: (observasi peneliti, 30 Januari 2020)

e. Alat Pembelajaran atau Media

Yakni, benda-benda yang berfungsi untuk memudahkan guru dalam menyampaikan materi (Dasopang, 2017:349-350). Dalam praktiknya, kegiatan ekstrakurikuler English Club di MIN 2 Sleman menggunakan media pembelajaran agar siswa mudah memahami materi. Media yang digunakan pun beragam sesuai tema pembelajaran yang akan disampaikan. Karena materi kosa kata sederhana, jadi media yang digunakan pun mudah ditemukan dan diadakan. Ciri khas media yang digunakan adalah bergambar, penuh warna, menarik, dan mudah dipahami. Seperti kalender untuk mengenalkan nama bulan, benda-benda di kelas untuk mengenalkan kosa kata tentang benda di 
kelas, poster, dan benda serta gambar lainnya sesuai tema yang dipelajari (Observasi peneliti, 30 Januari 2020).

\section{Hasil yang Dicapai dalam Kegiatan Ekstrakurikuler English Club di MIN 2 Sleman}

Kegiatan ekstrakurikuler English Club di MIN 2 Sleman sudah berjalan selama kurang lebih 10 tahun. Hal ini tentunya tidak hanya sekedar berjalan saja, namun harus ada output yang menjadi hasil kegiatan ekstrakurikuler tersebut. Beberapa tahun sejak ekstrakurikuler ini diadakan, MIN 2 Sleman sering mengikuti lomba olimpiade Bahasa Inggris dari tingkat sekolah sampai tingkat kabupaten. Namun sejak tahun terus berganti, kini olimpiade bahasa sudah ditiadakan diganti dengan Olimpiade Sains dan Matematika. Hal tersebut tidak membuat kegiatan ekstrakurikuler English Club terhenti, tetapi tetap berjalan seperti biasanya (Wawancara personal dengan IA, 4 Maret 2019).

Setelah peneliti melakukan wawancara, dan observasi di MIN 2 Sleman, peneliti mendapatkan hasil perkembangan kecerdasan linguistik siswa melalui kegiatan ekstrakurikuler English Club, di antaranya sebagai berikut:

a. Keterampilan Mendengar

Keterampilan mendengar siswa yang mengikuti ekstrakurikuler English Club di MIN 2 Sleman berkembang cukup baik. Hal ini ditunjukkan dari kemampuan siswa yang mudah memahami dan mengingat setiap kosa kata yang guru ajarkan. Guru mengulang-ulang kosa kata baru dan siswa mendengarkan dengan seksama hingga siswa bisa menyebutkan dan memahami makna atau perintah dari kosa kata tersebut (Observasi peneliti, 30 Januari 2020).

b. Keterampilan Berbicara

Keterampilan berbicara pada siswa yang mengikuti ekstrakurikuler English Club di MIN 2 Sleman berkembang dengan baik. Hal ini ditunjukkan dari sikap siswa di kelas yang responsif ketika guru memberi pertanyaan, mengajak berdiskusi, dan atau mengulang hafalan kosa kata dengan intonasi yang baik (observasi peneliti, 30 Januari 2020). Hasil dari keterampilan berbicara yang lain yang menjadi hasil unggulan bagi madrasah dari siswa English Club yaitu mampu menjadi receptionits (penerima tamu) pada saat madrasah memiliki acara tertentu, menyanyikan lagu berbahasa Inggris pada acara wisuda madrasah, dan menjadi pembawa acara (MC) pada acara wisuda madrasah dengan Bahasa Inggris (Wawancara personal dengan TW, 9 Januari 2020).

c. Keterampilan Menulis

Siswa yang mengikuti ekstrakurikuler English Club memiliki keterampilan menulis dengan baik. Selain mengulang-ulang kosa kata kepada siswa, guru menuliskannya di papan tulis atau membagikan hand out. Hal ini melatih siswa untuk terbiasa menulis dengan benar dan sesuai kosa kata. Siswa mampu menuliskan kembali dengan baik dalam kesempatan lain, seperti saat evaluasi bulanan, siswa juga menjadi senang menulis kegiatan sehari-harinya di rumah melalui buku diary (Wawancara personal dengan EF, 9 Januari 2020).

d. Keterampilan Membaca

Keterampilan membaca pada siswa yang mengikuti ekstrakurikuler English Club di MIN 2 Sleman berkembang dengan baik. Hal ini terlihat dari cara siswa membaca kosa kata dengan intonasi yang sesuai dan mampu membaca dengan lancar dan baik (Observasi peneliti, 30 Januari 2020). Di sisi lain, hal ini juga menumbuhkan minat membaca siswa ketika tidak di madrasah, seperti senang membaca dan berkunjung ke perpustakaan kota (Wawancara personal dengan siswa, 30 Januari 2020).

Dari beberapa hasil di atas, peneliti dapat menyimpulkan bahwa kegiatan ektrakurikuler Englih Club di MIN 2 Sleman berhasil mengembangkan kecerdasan linguistik siswa dari dasar hingga menghasilkan prestasi dalam berbagai bidang dan kepribadian yang baik.

\section{Faktor Pendukung dan Penghambat}


Dari implementasi hingga menuai keberhasilan, kegiatan ekstrakurikuler English Club tentunya tidak lepas dari beberapa faktor. Adapun faktor-faktor tersebut adalah:

a. Faktor Pendukung

Ada beberapa faktor yang mempengaruhi keberhasilan kegiatan ekstrakurikuler English Club di MIN 2 Sleman, yaitu:

1) Peran Kepala Madrasah yang kuat

Untuk mendukung keberhasilan kegiatan ekstrakurikuler English Club, kepala madrasah ikut sumbangsih dalam indikator pencapaian kegiatan ekstrakurikuler tersebut. Hal ini ditinjau dan diikuti perkembangannya oleh kepala madrasah untuk mengetahui apa saja yang perlu dibenahi dan dilengkapi dalam pelaksanaannya baik segi kurikulum maupun materi (Wawancara personal dengan TW, 9 Januari 2020).

2) Kualitas guru yang profesional

Guru sebagai pembina, pembimbing, dan tim pengembang ekstrakurikuler English Club di MIN 2 Sleman mempunyai latar belakang pendidikan yang sesuai, yaitu Pendidikan Bahasa Inggris. Setiap guru pembimbing mampu memahami tingkat kecerdasan bahasa/linguistik pada siswa, dan kreatif dalam menerapkan beberapa metode untuk memudahkan siswa dalam mengikuti kegiatan ekstrakurikuler ini (Wawancara personal dengan EF, 9 Januari 2020).

3) Minat dan kecerdasan siswa yang baik

Siswa yang mengikuti kegiatan ekstrakurikuler English Club merasa tidak kesulitan dalam menerima materi. Hal ini disebabkan adanya rasa suka belajar Bahasa Inggris, orang tua di rumah terbiasa mengajari Bahasa Inggris, mempunyai hobi yang dapat mengembangkan kecerdasan bahasanya seperti membaca di perpus, dan fasilitas yang memadai dari orang tua (Wawancara personal dengan siswa, 30 Januari 2020).

4) Alat atau media yang mudah didapat dan disediakan

Media atau alat yang digunakan dalam kegiatan ekstrakurikuler English Club cukup mudah dicari dan disediakan oleh madrasah. Hal ini disebabkan materi yang sampaikan termasuk kategori sederhana karena hanya untuk pengenalan Bahasa Inggris bagi siswa Madrasah Ibtidaiyah yang tidak sekomplek materi Bahasa Inggris tingkat madrasah menengah dan tingkat atas (Wawancara personal dengan EF, 9 Januari 2020).

b. Faktor Penghambat

Adapun beberapa faktor yang menghambat keberhasilan kegiatan ekstrakurikuler English Club di MIN 2 Sleman yaitu sebagai berikut:

1) Bukan materi wajib

Dalam Kurikulum 2013 untuk madrasah ibtidaiyah, Bahasa Inggris tidak lagi masuk masuk dalam materi pokok intrakurikuler. Sehingga waktu yang tersedia hanya berlangsung satu jam terasa sangat terbatas (Wawancara personal dengan EF, 9 Januari 2020).

2) Kurangnya minat bimbingan belajar di rumah

Menurut siswa yang mengikuti ekstrakurikuler English Club, karena Bahasa Inggris hanya sebatas kegiatan ektrakurikuler sehingga siswa merasa malas untuk mengikuti bimbingan belajar/les di rumah (Wawancara personal dengan siswa, 9 Januari 2020).

3) Media pembelajaran yang belum diperbarui

Pengadaan media yang bisa digunakan siswa sebagai media belajar sekaligus bermain di luar waktu kegiatan ekstrakurikuler tentunya bisa menciptakan kebiasaan yang mengembangkan kecerdasan bahasa siswa. Sayangnya, di MIN 2 Sleman masih sedikit ketersediaannya media permainan ini (Wawancara personal dengan EF, 9 Januari 2020). 


\section{PENUTUP}

Implementasi kegiatan ekstrakurikuler English Club di MIN 2 Sleman sudah berjalan selama kurang lebih sepuluh tahun. Kegiatan ini dikembangkan oleh tim yang profesional sesuai bidangnya. Tim bertugas mengevaluasi pelaksanaan kegiatan dan menginovasi metode sesuai kebutuhan siswa. Implementasi ekstrakurikuler ini meliputi dua tahapan, yakni tahapan persiapan dan tahapan proses. Dari kedua tahapan tersebut telah memberikan hasil yang dicapai, sehingga hasil tersebut dapat dipahami dalam konteks kecerdasan linguistik.

Dari hasil penelitian dapat dilihat bahwa hasil perkembangan kecerdasan linguistik siswa melalui kegiatan ekstrakurikuler English Club ini mencakup keterampilan mendengar, keterampilan berbicara, keterampilan menulis, dan keterampilan membaca. Di titik inilah kegiatan ektrakurikuler Englih Club telah berhasil mengembangkan kecerdasan linguistik pada diri siswa sejak dari pendidikan dasar sampai menghasilkan prestasi dan kepribadian lain yang baik.

\section{DAFTAR PUSTAKA}

A., Rose Mini, dkk. (2010). Panduan Mengenal dan Mengasah Kecerdasan Majemuk Anak. Jakarta Selatan: Indocam Prima.

Dasopang, Muhammad Darwis. (2017). "Belajar dan Pembelajaran". Fitrah: Jurnal Ilmu-Ilmu Keislaman. Vol. 03. No. 2. Desember.

Departemen Agama RI. (2005). Panduan Kegiatan Ekstra Kurikuler Pendidikan Agama Islam. Jakarta: Depag RI.

Dewi, Rosdiana, dkk. (2020). Implementasi Metode Sentra Persiapan dalam Mengembangkan Kecerdasan Verbal Linguistik Anak Usia Dini. Tarbiyatuna. Vol. 4. No. 1.

Djamarah, Syaiful Bahri. (2008). Psikologi Belajar. Jakarta: Rineka Cipta.

Hasbiansyah, O. (2008). "Pendekatan Fenomenologi: Pengantar Praktik Penelitian dalam Ilmu Sosial dan Komunikasi". Mediator. Vol. 9, No. 1, Juni.

Ichsan, Ahmad Shofiyuddin. (2020). Rekonsepsi Pendidikan Tahfiz Al Qur'an melalui Model Learning Styles pada Anak Usia Sekolah Dasar. Al Ulya: Jurnal Pendidikan Islam, Vol. 5 No 1.

Jannah, Rina Roudhotul, dkk. (2018). 144 Strategi Pembelajaran Anak Usia Dini Berbasis Multiple Intelligences. Yogyakarta: Ar Ruzz Media.

Jumiyati. (2018). Penanaman Kecerdasan Emosional dan Spiritual melalui Kegiatan Ekstrakurikuler dan Intrakurikuler di MI Ma'arif Sendang Karangsari Pengasih Kulonprogo. Tesis Program Studi Pendidikan Guru Madrasah Ibtidaiyah, Fakultas Tarbiyah dan Keguruan. Yogyakarta: UIN Sunan Kalijaga.

Kosim, Mohammad. (2008). "Madrasah Di Indonesia (Pertumbuhan dan Perkembangan)", Jurnal Tadris, Vol. 2. No. 1.

Kurniawati, Annis. (2011). Peran Penggunaan Media Flash Card dalam Penguasaan Kosakata Bahasa Inggris (vocabulary) pada Materi Family Kelas I di MIN Yogyakarta II, Skripsi Program Studi Pendidikan Guru Madrasah Ibtidaiyah Fakultas Tarbiyah dan Keguruan. Yogyakarta: UIN Sunan Kalijaga..

Martyawati, Widya Syahra. (2016). Peningkatan Kecerdasan Naturalis Siswa melalui Ekstrakurikuler Sains di MI Ma'arif NU 1 Pageraji Cilongok Banyumas, Tesis Program Studi Pendidikan Guru Madrasah Ibtidaiyah, Fakultas Tarbiyah dan Keguruan. Yogyakarta: UIN Sunan Kalijaga.

Masruroh, Laeliya. (2016). Pengembangan Media Interaktif Bahasa Inggris Menggunakan Adobe Flash Professional untuk Kegiatan Ekstrakurikuler di SD/MI, Skripsi Program Studi Pendidikan Guru Madrasah Ibtidaiyah Fakultas Tarbiyah dan Keguruan. Yogyakarta: UIN Sunan Kalijaga.

Mendikbud RI. (2014). Salinan Naskah Peraturan Menteri Pendidikan dan Kebudayaan Republik Indonesia tentang Kegiatan Ekstrakurikuler pada Pendidikan Dasar dan Pendidikan Menengah. Jakarta : Kemendikbud.

Moelong, Lexy J. (2011). Metodologi Penelitian Kualitatif. Bandung: PT Remaja Rosdakarya. 
Mustafidah, Arina. (2017). Implementasi Program Bilingual School untuk Meningkatkan Kecerdasan Verbal Bahasa Inggris di SD Intis Yogyakarta, Skripsi Program Studi Pendidikan Guru Madrasah Ibtidaiyah Fakultas Tarbiyah dan Keguruan. Yogyakarta: UIN Sunan Kalijaga.

Prihatin, Eka. (2011). Manajemen Siswa. Bandung: Alfabeta.

Racho, J. R. (2010). Metode Penelitian Kualitatif Jenis, Karakteristik, dan Keunggulannya. Jakarta: PT Grasindo.

Subini, Nini. (2011). Mengatasi Kesulitan Belajar pada Anak. Yogyakarta: Javalitera.

Sugiyono. (2018). Metode Penelitian Kuantitatif, Kualitatif, dan Kombinas (Mixed Methods). Bandung: Alfabeta.

Sulaiman, Umar. (2015). "Mengidentifikasi Kecerdasan Anak”.Al-Riwayah : Jurnal Kependidikan. Vol. 7. No. 2. September. 